\title{
CHEMOSPHERE
}

\section{Biodegradability of biofilm extracellular polymeric substances}

\author{
Xiaoqi Zhang ${ }^{\text {a,* }}$, Paul L. Bishop ${ }^{b}$ \\ a Department of Civil and Environmental Engineering, University of Massachusetts Lowell, One University Avenue, \\ Lowell, MA 01854, USA \\ ${ }^{\mathrm{b}}$ University of Cincinnati, Cincinnati, OH 45221-0018, USA
}

Received 17 December 2001; received in revised form 11 June 2002; accepted 14 June 2002

\begin{abstract}
This study discovered that biofilm extracellular polymeric substances (EPS) are biodegradable by their own producers and by other microorganisms when they are starved. The study was performed in a comparative fashion to examine the biodegradability of biofilm EPS by the microorganisms from the original biofilm (its own producers) and from activated sludge (other microorganisms). Four distinctive phases were observed during EPS biodegradation. In the first phase, instantaneous concentration increases of carbohydrate and protein in the test solutions were observed when EPS was added; in the second phase, easily biodegradable EPS from the added EPS was quickly utilized; in the third phase, microorganisms began to produce soluble EPS, using the minimally biodegradable EPS left from the previously added EPS; in the fourth phase, cells consumed the newly produced EPS and microbial activity gradually stopped. This study suggests that EPS can be used as a substrate, and that the EPS carbohydrate can be utilized faster than the EPS protein. The EPS utilization rates (including carbohydrate and protein) in the activated sludge suspension were greater than those in the biofilm suspension. It may take microorganisms longer to get acclimated to a new nutrient environment if they are in a starved state.
\end{abstract}

(c) 2002 Elsevier Science Ltd. All rights reserved.

Keywords: Carbohydrate; Protein; Lipid phosphate; Oxygen uptake rate; Activated sludge

\section{Introduction}

Extracellular polymeric substances (EPS) come from the natural secretions of bacteria, cell lysis and hydrolysis products. The predominant components of EPS are carbohydrate, protein, lipids, nucleic acids and various heteropolymers (Christensen, 1989; Lazarova and Manem, 1995). EPS composition determines many important properties of biofilm such as strength, elasticity, sorption capacity for adsorbents, etc. These properties are important for the behavior of biofilms in technical systems; for example, they can partly determine erosion and sloughing from biofilms, development of frictional

\footnotetext{
${ }^{*}$ Corresponding author. Tel.: +1-978-934-2287; fax: +1-978934-3052.

E-mail address: jackie_zhang@uml.edu (X. Zhang).
}

resistance in pipes, adsorption of solids from the bulk liquid and clogging of biofilters (Nielson et al., 1997). Our knowledge about the EPS is still limited. Recently, Nielson et al. (1997) presented a conceptual model which included production and degradation of all important organic constituents, including cell biomass and EPS components.

In pure cultures it has usually been assumed that the bacteria do not degrade their own exopolysaccharides, but this has now been shown not to be true for several types of bacteria (Boyd and Chakrabarty, 1994). Our hypothesis is that EPS is biodegradable and mixed cultures will degrade their own EPS material when they are in a starved state. Cells may not necessarily degrade their EPS under a nutrient rich condition, otherwise, the biomass glycocalyx would never become established. This research attempted to test the above hypothesis. The objectives were to investigate whether EPS can be 
utilized by its own producers or microorganisms other than their own producers when they are starved.

\section{Methods}

\subsection{Biofilms}

Aerobic heterogenous biofilms were grown in rotating drum biofilm reactors (RDBRs; Harmer, 1991). The RDBR has a rotating inner drum and a stationary outer wall. Four removable sampling slats are placed on the outer wall to facilitate biofilm sampling. Each slat has a dimension (height $\times$ width) of $20 \times 1 \mathrm{~cm}^{2}$. The reactor was initially seeded with wastewater from the Mill Creek Wastewater Treatment Plant, Metropolitan Sewer District of Greater Cincinnati, Ohio. The reactor was continuously fed with a synthetic wastewater with a COD of $150 \mathrm{mg} / \mathrm{l}$; glucose, yeast extract, beef extract and peptone were used as the substrate. The $\mathrm{pH}$ was maintained at about $7.0 \pm 0.2$ and bulk liquid dissolved oxygen (DO) was kept at $2-4 \mathrm{mg} / \mathrm{l}$. The composition of the synthetic wastewater can be found from Zhang (1999). Biofilm growth occurred on removable sampling slats. Biofilm sampling was done after a quasi-steady state was achieved. This occurred when the COD in the bulk solution reached about $20 \mathrm{mg} / \mathrm{l}$; it took three weeks to reach this quasi-steady state. During the sampling process, a slat was taken out of the reactor and the biofilm was removed from the slat using a sterilized blade.

\subsection{EPS extraction}

$8.2 \mathrm{~g}$ of biofilm sample were taken from the biofilm reactor when it reached the quasi-steady state. Biofilm EPS was extracted and harvested by using the regular centrifugation method described by Zhang et al. (1999). In the first step, the biofilm sample was put into a centrifugation tube along with $45 \mathrm{ml}$ MilliQ water; the tube was shaken gently and then centrifuged at $3500 \mathrm{rpm}$ $(6000 \mathrm{~g})$ for $10 \mathrm{~min}$. The liquid was decanted from the centrifuge tube and collected as the slime material. In the second step, the tube containing the biofilm pellets were filled with another $45 \mathrm{ml}$ MilliQ water; the contents were blended in a vortex blender at high speed for $1 \mathrm{~min}$ to recover the capsule-bound material. For the third step, liquids from the previous two steps were combined (resulting in a volume of $90 \mathrm{ml}$ ) and centrifuged at 12000 rpm for $30 \mathrm{~min}$ at room temperature. In the last step, the supernatant was collected and filtered through $0.22 \mu \mathrm{m}$ cellulose acetate filters to recover the EPS material. Later, $30 \mathrm{ml}$ of the extracted EPS was added into biofilm cell pellet suspensions. For the activated sludge suspensions, another piece of biofilm sample (7.8 g) was taken and extracted by following the same procedure, except that $70 \mathrm{ml}$ of MilliQ water was used during the extraction. DNA tests indicated no significant cell lysis occurred during the extraction procedure (Zhang et al., 1999). EPS yields in the extracts were represented by carbohydrate and protein yields, since they are the predominant components in the biofilm (Lazarova and Manem, 1995). A phenol-sulfuric acid (Gerhardt et al., 1994) method was used to quantify carbohydrate, with glucose as the standard. A modification of the Bradford (1976) method, called the Coomassie procedure (Pierce Chemical), was used to quantify protein, with Bovine Serum Albumin (BSA) as the standard. An HP 8453 UV-Vis diode-array (190-1100 nm) spectrophotometer was used for all measurements.

\subsection{Oxygen uptake rate}

Aerobes use oxygen as they consume food. The rate at which they use oxygen, the oxygen uptake rate, can be taken as a measure of their biological activity. High OURs indicate high biological activity; low OURs indicate low biological activity (Metcalf and Eddy, 1991). In this study, OUR was normalized by total suspended solids (TSS), indicating the amount of oxygen used by microorganisms. OUR was reported as $\mathrm{mg} \mathrm{O}_{2} / \mathrm{mg} \mathrm{TSS} /$ day to approximately represent the growth rate of the microorganisms. OUR was monitored according to Standard Methods (Clesceri et al., 1998).

\subsection{Biological parameters}

Biological properties of the biofilm were represented by its viable biomass and EPS amounts. The amounts of lipid phosphate and EPS were normalized with the TSS (Standard Methods, Clesceri et al., 1998) of the working solution to determine concentration profiles.

\subsubsection{Viable biomass}

Lipid phosphate analysis is a non-specific measure of viable biomass. Lipid phosphates are cellular constituents which are universally distributed among microorganisms and have a rapid turnover rate (Tepper, 1997). The method is based on a Bligh and Dyer (1959) extraction of lipids from bacterial membranes and refined by Findlay et al. (1989). During the procedure, further lipid metabolism ceases due to cell death, providing a snapshot of the lipids present at the time of extraction (Vestal and White, 1989). Usually several hours after the cells die, the phosphate group will detach from the lipid chain. Although dead cells can retain lipid phosphate until they lyse and are degraded, the chance for dead cells to contain a major share of the biofilm lipid phosphate should be very low. The measured lipid phosphate has a unit of $\mathrm{nmol} / \mathrm{ml}$. 


\subsection{Experimental setup}

After EPS extraction, the remaining solids are cell pellets. In order to find whether EPS can be used as a substrate by its own producers when there is only a limited food source for the cells, cell pellets were put into $300 \mathrm{ml}$ mineral solution without organic substrates (Zhang, 1999), re-suspended and aerated with air at room temperature to achieve a starved state. The OUR of the working solution was constantly monitored by transferring the working solution to a BOD bottle. A commonly used endogenous decay coefficient is 0.06 per day (Metcalf and Eddy, 1991). This number was used as a guideline in the OUR monitoring process. Kinetic studies began when the OUR reached $0.08 \mathrm{mg} \mathrm{O} / \mathrm{mg}$ TSS/day (close to the theoretical endogenous rate), indicating that the microorganisms were adequately starved. We then began to add $30 \mathrm{ml}$ of pre-extracted EPS to the remaining cell pellet suspensions (roughly $285 \mathrm{ml} \mathrm{left}$; some volume was lost during the transfer process when the OUR was measured). Fifteen milliliters of sample was taken from the suspensions periodically. Lipid phosphate was measured on the unfiltered sample. The rest of the sample was filtered to obtain the TSS and a clear filtrate, and then COD, carbohydrate, and protein in the filtrate were analyzed. Only one measurement was done for the TSS; duplicates were prepared for all the other analyses.

EPS was added as an aqueous solution. Table 1 shows the contribution of $30 \mathrm{ml}$ EPS to final working solutions. There is some lipid phosphate in the introduced EPS. It is possible that during the EPS extraction, a small amount of cell lysis occurred resulting in the capture of some lipids from the freshly lysed cells before the phosphate group had detached from the lipid chain.

Comparison experiments were done to determine whether EPS can be biodegraded by other microorganisms. A $150 \mathrm{ml}$ aliquot of activated sludge was taken from an aeration basin in the same wastewater treatment plant where the activated sludge was taken to seed the biofilm reactor. Hundred and fifty milliliters mineral solution was added to the activated sludge and the suspension was aerated to starve the cells. The OUR was constantly monitored. Kinetic studies were started when the OUR reached $0.08 \mathrm{mg} \mathrm{O}_{2} / \mathrm{mg}$ TSS/day. Slight variation of working volume occurred during the experiments because it took a longer time to starve the activated sludge suspensions (see Table 1).

It took three days for the OUR value to drop from 0.13 to $0.08 \mathrm{mg} \mathrm{O}_{2} / \mathrm{mg}$ TSS/day for the activated sludge suspensions, but only one day for biofilm cell pellets suspensions to reach an OUR of $0.08 \mathrm{mg} \mathrm{O} 2 / \mathrm{mg} \mathrm{TSS} /$ day. The difference between these two samples was that the activated sludge was not subjected to EPS extraction; however, EPS was extracted from the biofilm cell pellets. It took a longer time for the activated sludge suspensions to reach a lower OUR, indicating that EPS in the activated sludge might be used as additional food source.

\section{Results and discussion}

\subsection{EPS biodegradability by its own producers (biofilm)}

Immediately before adding the EPS material to the re-suspended cell pellets aerated with mineral solution, measurements were made of the carbohydrate, protein, and lipid phosphate in the solution to be used as the initial points (see Table 1). These three parameters were then continuously monitored over time.

Fig. 1 shows how carbohydrate, protein and viable biomass changed after adding EPS at an OUR of 0.08 $\mathrm{mg} \mathrm{O}_{2} / \mathrm{mg}$ TSS/day. The top graph shows the data normalized by TSS and the bottom graph shows the original data. The data points shown prior to time 0 represent the initial carbohydrate, protein and viable biomass amounts in the solution. The time 0 data points

Table 1

Contribution of $30 \mathrm{ml}$ pre-extracted EPS to final working solutions (OUR $=0.08 \mathrm{mg} \mathrm{O}_{2} / \mathrm{mgTSS} /$ day)

\begin{tabular}{|c|c|c|c|c|}
\hline & \multicolumn{2}{|c|}{$\begin{array}{l}\text { EPS biodegradability by its own producers } \\
\text { (initial biofilm amount EPS was extracted } \\
\text { from } 8.2 \mathrm{~g} / 90 \mathrm{ml} \text { ) }\end{array}$} & \multicolumn{2}{|c|}{$\begin{array}{l}\text { EPS biodegradability by other microor- } \\
\text { ganisms (initial biofilm amount EPS was } \\
\text { extracted from } 7.8 \mathrm{~g} / 70 \mathrm{ml} \text { ) }\end{array}$} \\
\hline & $30 \mathrm{ml}$ EPS & $\begin{array}{l}285 \mathrm{ml} \text { biofilm cell pellets } \\
\text { suspensions }+30 \mathrm{ml} \text { EPS }\end{array}$ & $30 \mathrm{ml}$ EPS & $\begin{array}{l}270 \mathrm{ml} \text { activated sludge } \\
\text { suspensions }+30 \mathrm{ml} \text { EPS }\end{array}$ \\
\hline $\mathrm{TSS}(\mathrm{mg} / 1)$ & 0 & 245 & 0 & 855 \\
\hline $\mathrm{COD}(\mathrm{mg} / 1)$ & $23.0^{\mathrm{a}} \pm 0.8$ & $96.4 \pm 2.8$ & $26.1^{\mathrm{b}} \pm 0.3$ & $126.3 \pm 3.0$ \\
\hline COD/TSS (mg/g) & $93.9 \pm 3.3$ & $393.5 \pm 11.4$ & $30.5 \pm 0.4$ & $147.7 \pm 3.5$ \\
\hline Carbohydrate (mg/g TSS) & $8.1 \pm 1.2$ & $67.2 \pm 1.6$ & $2.0 \pm 0.1$ & $20.6 \pm 0.0$ \\
\hline Protein (mg/g TSS) & $13.3 \pm 0.1$ & $29.9 \pm 0.3$ & $3.0 \pm 0.0$ & $5.9 \pm 1.2$ \\
\hline Lipid phosphate (nmol/mg TSS) & $2.0 \pm 0.0$ & $86.8 \pm 0.0$ & 0 & $19.6 \pm 1.3$ \\
\hline
\end{tabular}

${ }^{\mathrm{a}}$ COD of initial $30 \mathrm{ml}$ EPS was $241.4 \pm 8.7(\mathrm{mg} / 1)$, so $241.4 \times 30 / 315=23.0 \pm 0.8(\mathrm{mg} / 1)$ was added.

${ }^{\mathrm{b}}$ COD of initial $30 \mathrm{ml}$ EPS was $261.3 \pm 3.3(\mathrm{mg} / 1)$, so $261.3 \times 30 / 300=26.1 \pm 0.3(\mathrm{mg} / 1)$ was added. 


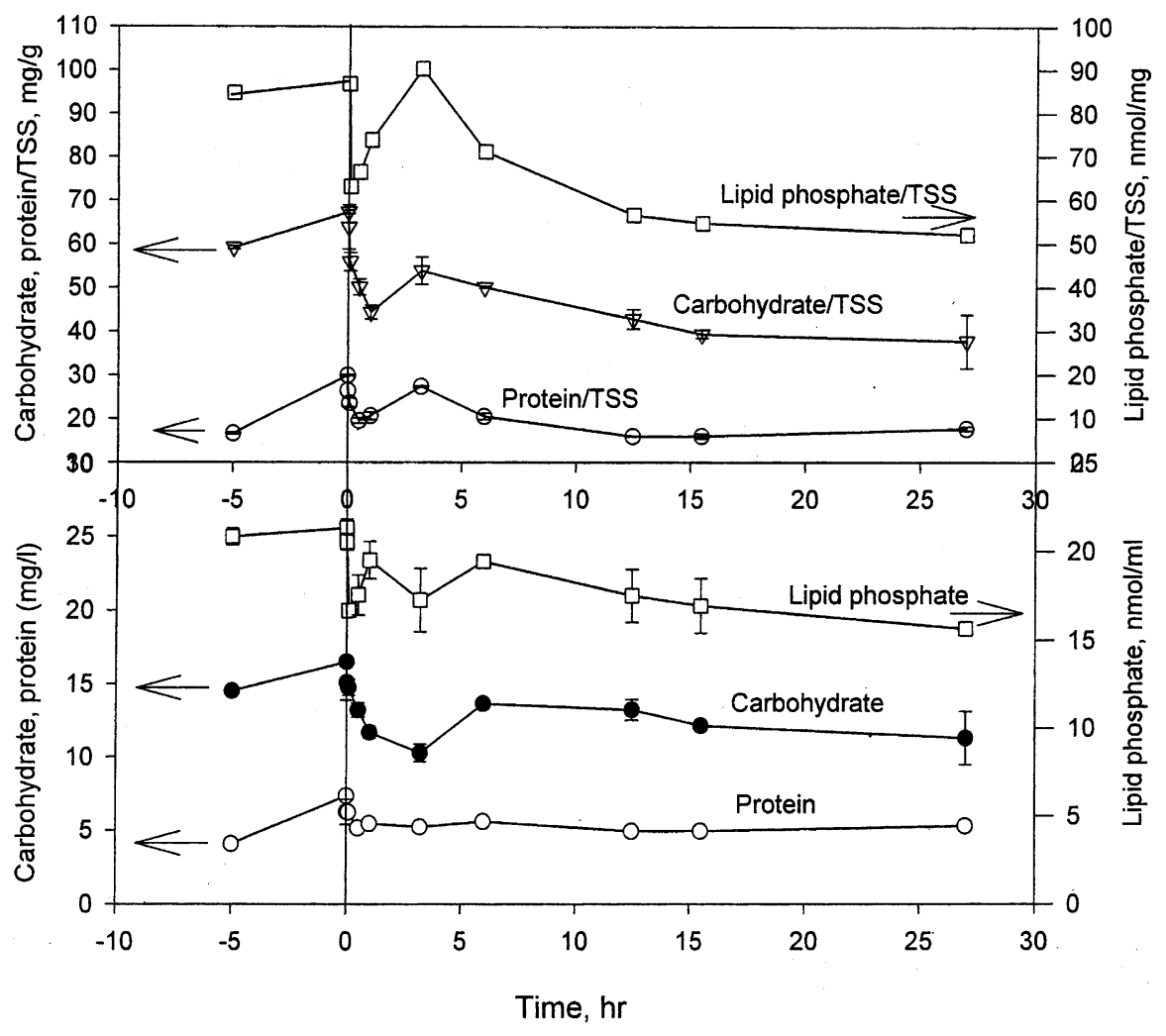

Fig. 1. EPS biodegradability and viable biomass production (by its own producers, OUR $=0.08 \mathrm{mg} \mathrm{O}_{2} / \mathrm{mg} \mathrm{TSS} / \mathrm{day}$ ).

refer to the new concentrations resulting from the added EPS material. It appears that some carbohydrate and protein materials were still trapped in the cell pellets after extraction and were later released once the cell pellets were re-suspended in the mineral solution.

In Fig. 1, there are four distinctive phases. In the first phase, we see a concentration increase from the EPS pulse feed; carbohydrate/TSS changed from $59.2 \pm 0.4$ to $67.2 \pm 1.6 \mathrm{mg} / \mathrm{g}$, and protein/TSS changed from $16.6 \pm 0.2$ to $30.0 \pm 0.3 \mathrm{mg} / \mathrm{g}$. In the second phase, the added EPS quickly decreased $30 \mathrm{~min}$ to $1 \mathrm{~h}$ after the EPS addition; the concentration of carbohydrate/TSS changed from $67.2 \pm 1.6$ to $44.3 \pm 1.6 \mathrm{mg} / \mathrm{g}$, and the concentration of protein/TSS changed from $30.0 \pm 0.3$ to $19.5 \pm 0.6 \mathrm{mg} / \mathrm{g}$, probably indicating that the easily biodegradable EPS was quickly utilized. In the third phase, after $3 \mathrm{~h}$ incubation, the concentration of carbohydrate/TSS increased from $44.3 \pm 1.6$ to $53.9 \pm 3.1$ $\mathrm{mg} / \mathrm{g}$, and the concentration of protein increased from $19.5 \pm 0.6$ to $27.4 \pm 0.2 \mathrm{mg} / \mathrm{g}$. This probably indicates that the microorganisms produced soluble EPS using the minimally biodegradable EPS left from the added EPS. In the fourth phase, the concentrations of carbohydrate and protein dropped and then vanished, indicating that cells used the newly produced EPS as a substrate. After it was used up, the microbial activity gradually stopped.
The concentrations of lipid phosphate/TSS indicated the same trend, corresponding to the same changing EPS processes. In the first phase, a small amount of lipid phosphate was probably introduced into the working suspensions from the added EPS. It is possible that, during the EPS extraction, we captured some of the lipids that came from the freshly lysed cells, but the amounts were small. In the second phase, there was no increase in lipid phosphate amount; microorganisms were probably just beginning to metabolize the EPS supplied as a substrate, but had not yet started reproducing themselves. But in the third phase, the microorganisms not only reproduced themselves, they also started to produce more soluble EPS. In the fourth phase, microorganisms gradually lost their reproduction ability, lysed and finally stopped their activity.

The bottom graph indicates how the un-normalized soluble EPS amounts and lipid phosphate change over time. Similar trends are exhibited. During the initial EPS consumption (second phase), cells vigorously took up EPS as an external food source, but had not yet started reproducing; therefore, both the carbohydrate and the protein showed a decreasing trend. However, after the EPS began to be biodegraded, some enzymes in the cells were probably turned on and cells started to produce more cells (more lipid phosphate) and new EPS (third 


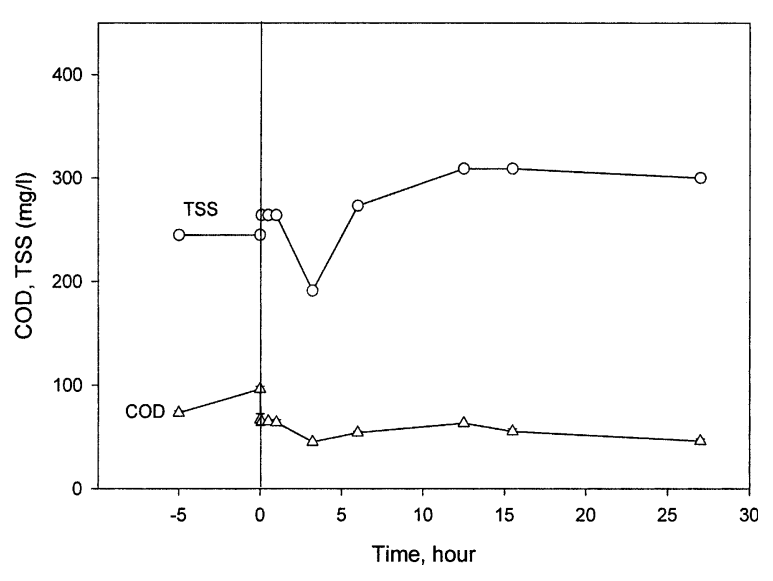

Fig. 2. Soluble COD and TSS change over time (by its own producers, OUR $=0.08 \mathrm{mg} \mathrm{O}_{2} / \mathrm{mg} \mathrm{TSS} /$ day).

phase). Eventually, though, the newly produced EPS was used up again and the cells lost their microbial activity.

In phase 2, simple regression indicates that the initial EPS consumption process was a zero-order reaction, indicating that the initial EPS consumption rates were concentration independent. The carbohydrate utilization rate was $0.4 \mathrm{mg}$ carbohydrate/mg TSS/day; the protein utilization rate was $0.3 \mathrm{mg}$ protein $/ \mathrm{mg} \mathrm{TSS} /$ day. Zero-order reactions usually happen when the food supply is abundant. So it is possible that the supplied EPS was sufficient for the starved microorganisms to consume in the second phase, or that their food consumption rate was limited by the long starvation time. Since this finding is the result of a simple regression, further study of the reaction order and mechanisms needs to be done in the future.

Fig. 2 shows how the soluble COD and TSS of the suspensions change over time. Soluble COD can be viewed as the overall expression of the biodegradable materials and non-biodegradable materials in the solution, while TSS represents the total biomass. In the second phase, the drop of soluble COD corresponds with the consumption of the added carbohydrate and protein, indicating that the added EPS is quickly biodegraded. The TSS trend follows that of the lipid phosphate in Fig. 1, except that phase 4 does not exist because there is not sufficient time for the solids to be significantly biodegraded.

\subsection{EPS biodegradability by other microorganisms (ac- tivated sludge)}

Comparative studies were performed using activated sludge to evaluate whether biofilm EPS can be biodegraded by other microorganisms at a comparable OUR of $0.08 \mathrm{mg} \mathrm{O}_{2} / \mathrm{mg}$ TSS/day. Similar results to those reported above were observed (see Fig. 3).
In the activated sludge suspensions, results for soluble COD (mg/l) and TSS (mg/l) (Fig. 4) correspond well with EPS/TSS, soluble carbohydrate and protein measurements shown in Fig. 3, indicating that soluble COD corresponds to the soluble EPS in the suspensions. In the first phase, COD increased due to the added EPS; in the second phase, it decreased after the first $30 \mathrm{~min}$. This may be explained by the soluble EPS material probably being consumed as substrate, which induced the decrease in the soluble COD concentration. In the third phase, COD increased again, verifying our hypothesis that cells started to reproduce more soluble EPS. In the fourth phase, COD decreased and then stayed at a constant level; it is possible that some newly produced EPS was also consumed as substrate. Also, lysis may happen in the fourth phase (lysed material could also be used as food), and eventually the microorganisms gradually lost their microbial activity.

Experiments were also performed at another oxygen uptake rate (i.e., $0.06 \mathrm{mg} \mathrm{O}_{2} / \mathrm{mg} \mathrm{TSS} /$ day) for biofilm cell pellet suspensions and activated sludge suspensions. EPS utilization rates during the initial consumption phase are shown in Table 2. Under both oxygen uptake rate conditions, the carbohydrate utilization rate was higher than the protein utilization rate, indicating that carbohydrate was utilized faster than was protein. Comparing the behavior of biofilm suspensions and activated sludge suspensions, activated sludge exhibited higher utilization rates for carbohydrate and protein than did the biofilm (except at an OUR of $0.08 \mathrm{mg}$ $\mathrm{O}_{2} / \mathrm{mg}$ TSS/day, where the protein utilization rate was lower). This is probably because the activated sludge had a more diverse variety of microorganisms, allowing it to take less time to get acclimated to the new nutrient environment. We believe that certain selection occurred while growing the biofims in the laboratory reactors due to the synthetic feed used. Comparing the behavior of biofilm and activated sludge at the two different oxygen uptake rates, we found that the utilization rates for carbohydrate and protein for both biofilm and activated sludge suspensions were greater at an OUR of $0.08 \mathrm{mg}$ $\mathrm{O}_{2} / \mathrm{mg}$ TSS/day than at an OUR of $0.06 \mathrm{mg} \mathrm{O} 2 / \mathrm{mg}$ TSS/ day. This indicates that it may take microorganisms longer to become acclimated to a new nutrient environment if they are highly starved.

It is noted that the final concentrations of carbohydrate/TSS are even lower than their initial concentrations. This is probably due to the so-called "priming effect", where decomposition of organics is stimulated. The possible explanation is that there was a buildup of a large and vigorous population of microorganisms when energy material (EPS) was added to the biofilm cell pellets/activated sludge suspensions, and these microorganisms subsequently produced enzymes which attacked the native organic matter (Stevenson, 1982). 


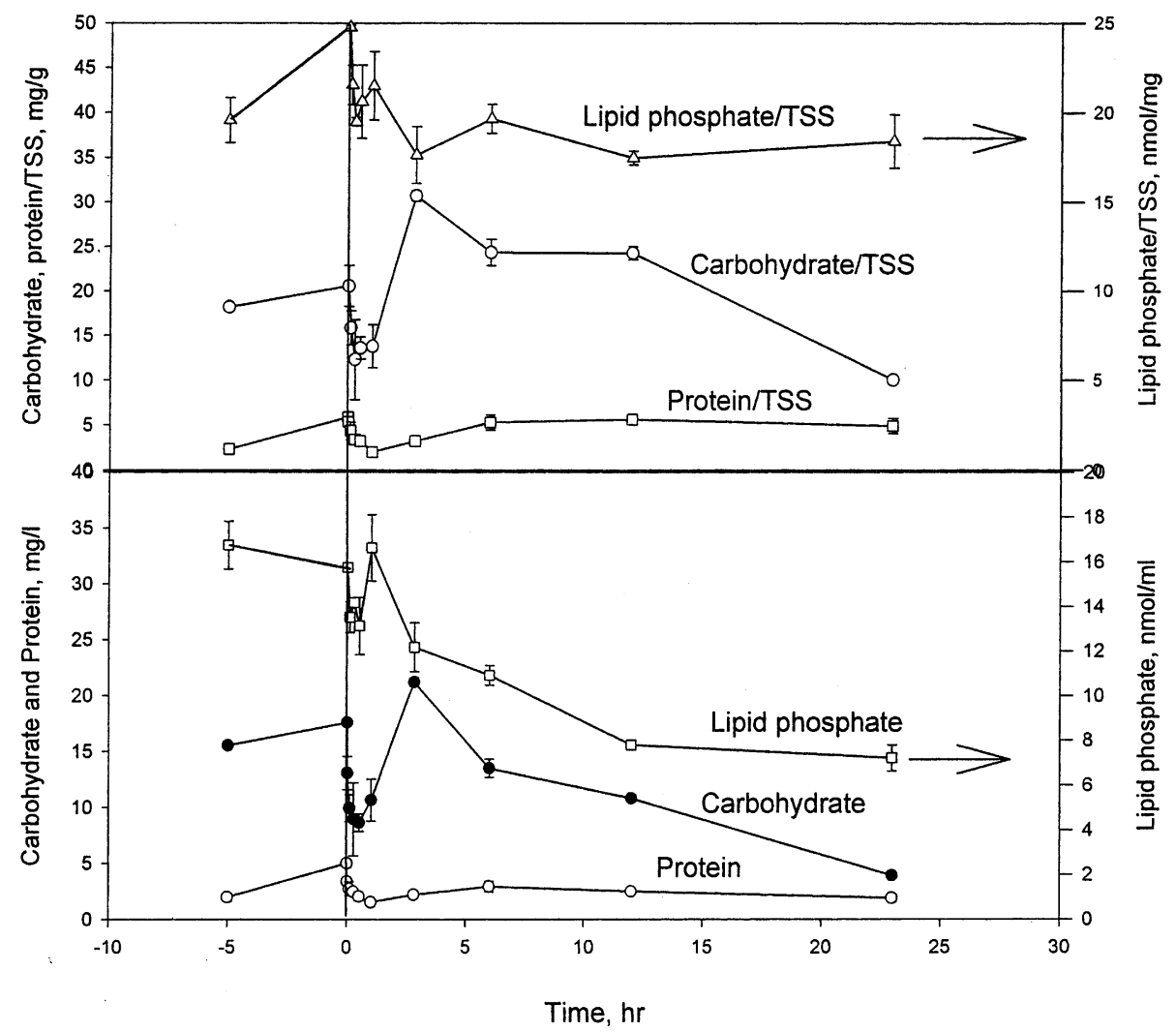

Fig. 3. EPS biodegradability and viable biomass production (by other microorganisms, OUR $=0.08 \mathrm{mg} \mathrm{O}_{2} / \mathrm{mg} \mathrm{TSS} / \mathrm{day}$ ).

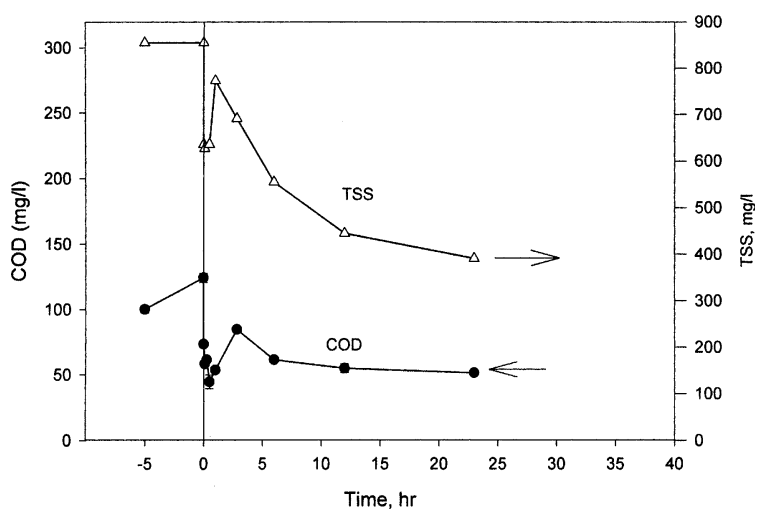

Fig. 4. Soluble COD and TSS change over time (by other microorganisms, OUR $=0.08 \mathrm{mg} \mathrm{O}_{2} / \mathrm{mg} \mathrm{TSS} /$ day).

\section{Conclusions}

This study found that biofilm EPS was biodegradable by its own producers as well as by other microorganisms. Based on the above experimental evidence, we believe that the following events occurred during the EPS biodegradability study (see Fig. 5). There were four
Table 2

Comparison of EPS utilization rates

\begin{tabular}{lllll}
\hline & $\begin{array}{l}\text { Biofilm cell } \\
\text { pellets sus- } \\
\text { pensions }\end{array}$ & \multicolumn{2}{l}{$\begin{array}{l}\text { Activated } \\
\text { sludge sus- } \\
\text { pensions }\end{array}$} \\
\hline OUR (mg O $/$ /mg TSS/day) & 0.06 & 0.08 & 0.06 & 0.08 \\
$\begin{array}{l}\text { Utilization rate of carbo- } \\
\text { hydrate (mg/mg TSS/day) }\end{array}$ & 0.14 & 0.41 & 0.22 & 0.73 \\
$\begin{array}{l}\text { Utilization rate of protein } \\
\text { (mg/mg TSS/day) }\end{array}$ & 0.04 & 0.30 & 0.07 & 0.07 \\
\hline
\end{tabular}

distinctive phases. In phase 1 , the working solution containing re-suspended cell pellets received a pulse source of substrate from the added EPS. In phase 2, easily biodegradable EPS was quickly consumed. In phase 3, microorganisms produced soluble EPS, which was added to the minimally biodegradable EPS left from the initially added EPS. In phase 4, newly produced soluble EPS was further consumed and microbial activity gradually stopped.

This study revealed that EPS can be used as a substrate, and that carbohydrate was utilized faster than was protein. The EPS utilization rates (including carbohydrate and protein) in the activated sludge suspen- 


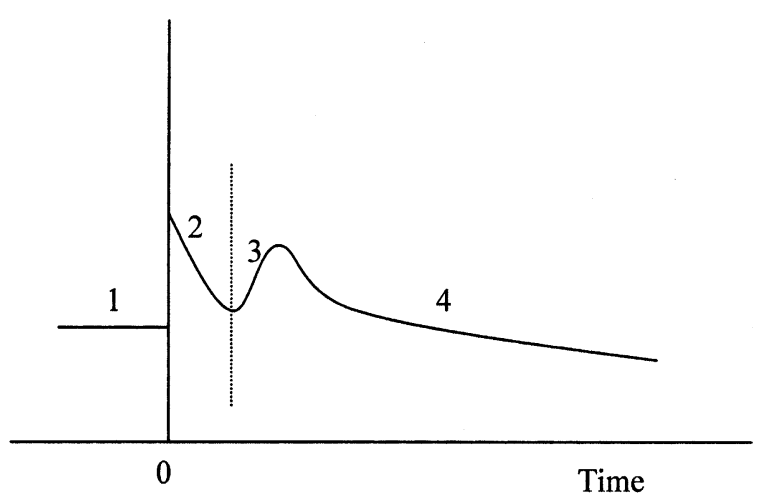

Fig. 5. EPS biodegradability mechanisms: (1) pulse source of substrate from the added EPS; (2) easily biodegradable EPS was consumed; (3) produced soluble EPS plus minimally biodegradable EPS left; (4) newly produced EPS was further consumed and activity gradually stopped.

sions were greater than those in the biofilm suspensions. It may take microorganisms longer to get acclimated to a new nutrient environment if they are highly starved.

The results of this research can lead to a better understanding of flocculation/deflocculation processes and contribute to the biofilm modeling endeavor.

\section{Acknowledgement}

This project was funded by the Superfund Basic Research Program of the National Institute of Environmental Health Sciences (NIEHS).

\section{References}

Bligh, E.G., Dyer, W.J., 1959. A rapid method of total lipid extraction and purification. Can. J. Biochem. Physiol. 37, 911-917.

Boyd, A., Chakrabarty, A.M., 1994. Role of alginate lyase in cell detachment of Pseudomonas aeruginosa. Appl. Environ. Microbiol. 60, 2355-2359.
Bradford, M.M., 1976. A rapid and sensitive method for the quantification of microgram quantities of protein utilizing the principle of protein-dye binding. Anal. Biochem. 72, 248-254.

Christensen, B.E., 1989. The role of extracellular polysaccharides in biofilms. J. Biotechnol. 10, 181-202.

Clesceri, L.S., Greenberg, A.E., Eaton, A.D., 1998. Standard Methods for the Examination of Water and Wastewater, 20th ed. American Public Health Association/American Water Works Association/Water Environment Federation, Washington, DC.

Findlay, R.H., King, G.M., Watling, L., 1989. Efficiency of the phospholipid analysis in determining microbial biomass in sediments. Appl. Environ. Microbiol. 55, 28882893.

Gerhardt, P., Murray, R.G.E., Wood, W.A., Krieg, N.R., 1994. Methods for General and Molecular Bacteriology. American Society for Microbiology, Washington, DC.

Lazarova, V., Manem, J., 1995. Biofilm characterization and activity analysis in water and wastewater treatment. Water Res. 29, 2227-2245.

Harmer, C., 1991. Factors affecting secondary utilization kinetics of azo dye in wastewater biofilms. M.S. Thesis, University of Cincinnati, Cincinnati, OH, USA.

Metcalf and Eddy, Inc., 1991. Wastewater Engineering: Treatment, Disposal, and Reuse, third ed. McGraw-Hill, New York.

Nielson, P.H., Jahn, A., Palmgren, R., 1997. Conceptual model for production and composition of exopolymers in biofilms. Water Sci. Technol. 36 (1), 11-19.

Stevenson, F.J., 1982. Humus Chemistry: Genesis, Composition, and Reactions. John Wiley \& Sons, Inc., New York.

Tepper, A., 1997. Aerobic azo dye degradation by Sphingomonas isolates in wastewater treatment biofilms. M.S. Thesis, University of Cincinnati, OH, USA.

Vestal, J.R., White, D.C., 1989. Lipid analysis in microbial ecology. Bioscience 39, 535-541.

Zhang, X., 1999. Biofilm Extracellular Polymeric Substances (EPS)-Methodology Development, Spatial Distribution and Property Investigation. Ph.D. Dissertation, University of Cincinnati, Cincinnati, OH, USA.

Zhang, X., Bishop, P.L., Kinkle, B.K., 1999. Comparison of extraction methods for quantifying extracellular polymers in biofilms. Water Sci. Technol. 39 (7), 211-218. 